\title{
Phenotypic and Reproductive Parameters of Barking Deer Under Management Condition of Chittagong Zoo
}

\author{
Omar Faruk Miazi ${ }^{1}$, , Gous Miah ${ }^{1}$, Tahmina Bilkis ${ }^{1}$, Md. Kabirul Islam Khan ${ }^{1}$, Ashutosh Das ${ }^{1}$, \\ Md. Moksedul Momin ${ }^{1}$, Mohammad Showkat Mahmud ${ }^{2}$, Palash Chandra Dey ${ }^{1}$ \\ ${ }^{1}$ Department of Genetics and Animal Breeding, Chittagong Veterinary and Animal Sciences University Khulshi, Chittagong, Bangladesh \\ ${ }^{2}$ Bangladesh Livestock Research Institute, Savar, Dhaka, Bangladesh
}

\section{Email address:}

f_cvasu@yahoo.co.in (O. F. Miazi)

${ }^{*}$ Corresponding author

\section{To cite this article:}

Omar Faruk Miazi, Gous Miah, Tahmina Bilkis, Md. Kabirul Islam Khan, Ashutosh Das, Md. Moksedul Momin, Mohammad Showkat Mahmud, Palash Chandra Dey. Phenotypic and Reproductive Parameters of Barking Deer Under Management Condition of Chittagong Zoo. International Journal of Genetics and Genomics. Vol. 4, No. 5, 2016, pp. 40-44. doi: 10.11648/j.ijgg.20160405.11

Received: October 30, 2016; Accepted: November 21, 2016; Published: January 3, 2017

\begin{abstract}
The study was conducted to know about the phenotypic parameters and reproductive parameters of barking deer under feeding management at Chittagong Zoo. Data were collected for a period of 3 months from 04 deer from $1^{\text {st }}$ September 2013 to $30^{\text {th }}$ November 2013 on all age groups. The deer were kept within an open enclosure measured as $66.52 \mathrm{~m}^{2}$ with a fence of chain link mash, $3.6 \mathrm{~m}$ in height. Available feeds supplied to deer were gram, rice bran, green gourd, pumpkin, carrot and amloki. The coat color was reddish and "V" Shaped black colored forehead and black colored muzzle. The ear length of males and females were $3.5 \pm 0.5$ and 3.5 inch. The length of foreleg for male and female were 20 and 19 inch and the length of hind leg for male and female were 22 and 21 inch. The length of antlers was 3 inch. Distance between ear of male and female were 3.7 and 3.6 inch. The average birth weight of males and females were ranging from $1-1.5 \mathrm{~kg}$ and $0.5-0.7 \mathrm{~kg}$, males and females weaning weight were ranging from 10-12 kg and 08-10 kg respectively. Adult male's and female's weight were ranging from $25-30 \mathrm{~kg}$ and $20-25 \mathrm{~kg}$. It was also observed that the weaning age, length of estrous cycle, age at first fawning and gestation length were ranging from 4-6 months; 12-20 days, 14-18 month and 6-7 month, respectively.
\end{abstract}

Keywords: Barking Deer, Chittagong Zoo, Phenotypic Characters, Reproductive Parameters

\section{Introduction}

Deer are perhaps the most ancient of all the typical ruminants, making their appearance in the lower Miocene, where the species were of small size and for the most part unprovided with antlers [13]. Deer found throughout the world either in the wild or as farmed animals. The Indian Muntjac (Muntiacus muntjak) is commonly called the "barking deer" due to the bark-like sound that it makes as an alarm when danger is present. Sometimes these deer will bark for an hour or more. This is widespread throughout Southern Asia, but is one of the least known Asian animals.

Muntjacs have a reddish coat of a rather uniform hue, without any conspicuous markings on the legs or tail. The color of the belly and the inside of the legs are a little paler. The tail is short and pointed, the muzzle is rather large and black. There are no noticeable seasonal changes in coat color. Newborn have a spotted coat, but since they are very small and remain hidden rather than following their mother during the first few weeks of life, one is unlikely to see spotted fawns in the field. There is no sexual difference in coat colour except for the two black lines that run along the antler pedicles of males and that extend down the face. Both sexes have large preorbital glands located at the corner of the eyes that appear as a sigmoid fold of skin right in front of the eye. They are larger in males and are very conspicuous when reverted prior to marking with them or during intense aggressive interactions [3] [4] [9]. In addition both sexes have a pair of frontal glands: two straight slits on the face, between the eyes [3]. Males are only a little larger than females in body weight (e.g. about $22 \mathrm{~kg}$ vs $20 \mathrm{~kg}$ ) [15].

The Indian Muntjacs are polygamous animals. Females 
reach puberty during their first to second year of life. These females are polyestrous, with each cycle lasting about 14 to 21 days and an estrus lasts for 2 days. The gestation period is 6 to 7 months and they usually bear one offspring at a time but sometimes produce twins. Females usually give birth in dense growth so that they are hidden from the rest of the herd and predators. The young leaves its mother after about six months to establish its own territory. Stags often fight between one another for possession of mating the does. Indian Muntjacs are distinguished from other ungulates in showing no evidence of a specific breeding season within the species given its wide geographical range and its great adaptability, the species $M$. muntjac as a whole may be one of the least threatened deer in the region. The IUCN gives status to all ten subspecies of M. muntjak [17] presumably on the basis of sufficient data.

Conservation of nature and natural resources is now a global concern. The world deer industry is growing about $20 \%$ annually \& about five millions deer's currently being farmed. Without proper scientific knowledge on conservation management, natural resource utilization is very difficult. No other study has been performed like this. The objective of the study was to know the phenotypic characters and reproductive parameters of the barking deer of Chittagong Zoo.

\section{Materials and Methods}

\subsection{Study Period}

The study was carried out from $1^{\text {st }}$ September, 2013 to $30^{\text {th }}$ November, 2013 at Chittagong Zoo.

\subsection{Study Location}

The study was conducted at Chittagong Zoo which is located at Khulshi, Pahartali, Bangladesh adjacent to Foy's lake. The Zoo was established at $28^{\text {th }}$ February, 1989. Its total area is about 6.0 acres. The land of the zoo is covered with sloppy, hilly, flat bends along the side lakes with steep sides. There is natural forest over the hills with good numbers of trees within the zoo area. The zoo is surrounded by a boundary wall of about six feet high. At present there are about 67 species and total number of animals is about 365 .

\subsection{Study Population}

There are four species of deer in Chittagong Zoo. These are Spotted Deer (Axix axis), Barking Deer (Muntiacus muntjak), Sambar Deer (Cervus unicolor) and Hog Deer (Axis porcinus)).

Table 1. Deer population at Chittagong Zoo.

\begin{tabular}{ll}
\hline Species of Deer in ChittagongZoo & Population size \\
\hline 1. Barking Deer (Muntiacus muntjak) & 04 \\
2. Spotted Deer (Axix axis) & 08 \\
3. Sambar Deer (Cervus unicolor) & 03 \\
4. Hog Deer (Axisporcinus) & 01 \\
\hline
\end{tabular}

The study was carried out on the management of Barking Deer. Four barking deer consisting of adult male (02), adult female (01) \& juvenile (01) were present at the time of the study.

\subsection{Feeding of Deer}

In this study, it was observed that. Feeding of Barking Deer was devoid of green fodder, where as vegetables (Lau, Misty Kumra and Carrot @ of 1.8 kg, 1.8 kg and 1.6 kg per animal per day respectively) and concentrates (Gram and Rice bran@0.3 kg and $1.0 \mathrm{~kg}$ respectively) were supplied only. Green fodder was not given due to the parasitic infestation load said by zoo authority. After several parasitic infestations, green fodder supplement was stopped. Additionally amloki was given when available in the market (a) 20gm per individual deer.

Table 2. Feeding status of Barking Deer at Chittagong Zoo.

\begin{tabular}{llll}
\hline Feed Ingredients & \multicolumn{1}{l}{ Amount supplied $(\mathbf{k g}) /$ animal/ day } & Total (kg)/ animal/ day \\
\hline & Fore noon & After noon & \\
\hline 1. Gram & 0.15 & 0.15 & 0.3 \\
2. Rice bran & 0.5 & 0.5 & 1.0 \\
3. Green gourd & 1.0 & 0.8 & 1.8 \\
4. Pumpkin & 1.0 & 0.8 & 1.8 \\
5. Carrot & 0.80 & 0.80 & 1.5 \\
6. Amloki* & 0.02 & 0.02 & 0.04 \\
7. Common Salt & 0.001 & 0.401 & 0.001 \\
Total & 3.121 & 3.121 & 6.242 \\
\hline
\end{tabular}

*Seasonal, based on availability.

Here vegetables and concentrate were supplied altogether where as [1] reported, concentrates are fed in the forenoon plus seasonal fresh grass and vegetables in the afternoon. In case of pregnancy, the amount of feed is increased. Feeds were calculated as individual basis then given altogether for the Deer. In morning, feed were supplied around 11.00 am and around $4.00 \mathrm{pm}$ in the evening session. This ration for Barking Deer was not formulated on any standard in respect to their annual requirement for crude protein (CP) and metabolisable energy (ME). Here $\mathrm{AD}_{3} \mathrm{E}$, Calphos vet and 
DB vitamin were supplied as vitamin mineral source, for 10 days consecutively and then made an interval of ten days and again continue. Normal Saline was given in summer season to reduce stress. In Chittagong Zoo, it was observed that water was supplied once daily, more or less 5 liter per day for Barking deer.

\subsection{Collection of Data}

Data were collected on physical visit to the Zoo. The following characters were recorded.

\subsubsection{Phenotypic Characteristics}

- Body coat color was estimated by direct visual observation.

- Length of ear was taken by measuring tape from the base to tip of ear.

- Length of fore and hind legs were taken by tape from hip joint to hoof.

- Tail was taken by tape from the base to the tip of tail.

- Length of antler was taken by tape from the base to the tip of antler.

- Weight measures of different aged deer by measuring scale. Without this adult male and female

weight were collected several times, which were varied in several times.

\subsubsection{Reproductive Parameters}

Information about puberty, length of estrous cycle, gestation period, age at firstfawning, litter size, weaning period, survival rate (mortality of fawns) \& other special traits were taken from the zoo record book by using questionnaire.

\subsection{StudyProcedures}

During the study period (12 weeks) the zoo was visited in every alternative day. Most of the management practices were observed physically and required data were collected from the record books of the zoo with the coordination of the Zoo authority in addition to current data.

The collected data were analyzed by using the statistical program of computer, Microsoft word, Microsoft Excel and ANOVA.

\section{Results and Discussions}

Phenotypic Characters and Parameters

The phenotypic characters and parameters of the Barking Deer were observed during the study period and the findings of the study are discussed in a tabular form in below.

Table 3. Phenotypic Characters of Barking Deer.

\begin{tabular}{ll}
\hline Points & Characters \\
\hline Body coat color & Reddish \\
Forhead. & "V" shaped black colored \\
Muzzle. & Black colored \\
\hline
\end{tabular}

In this study, the body coat color was reddish which is similar to the findings of [13] (reddish).

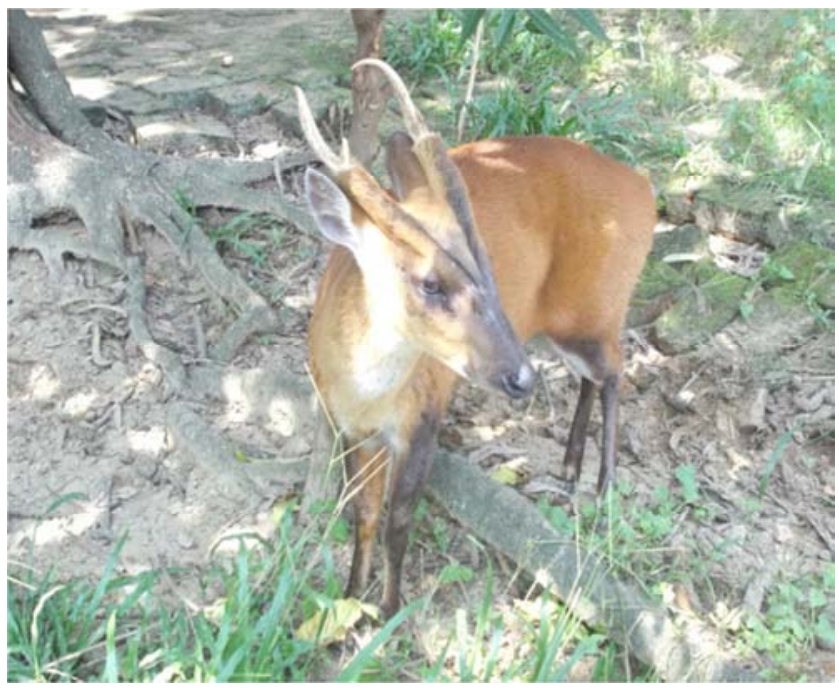

Figure 1. Male Barking Deer.

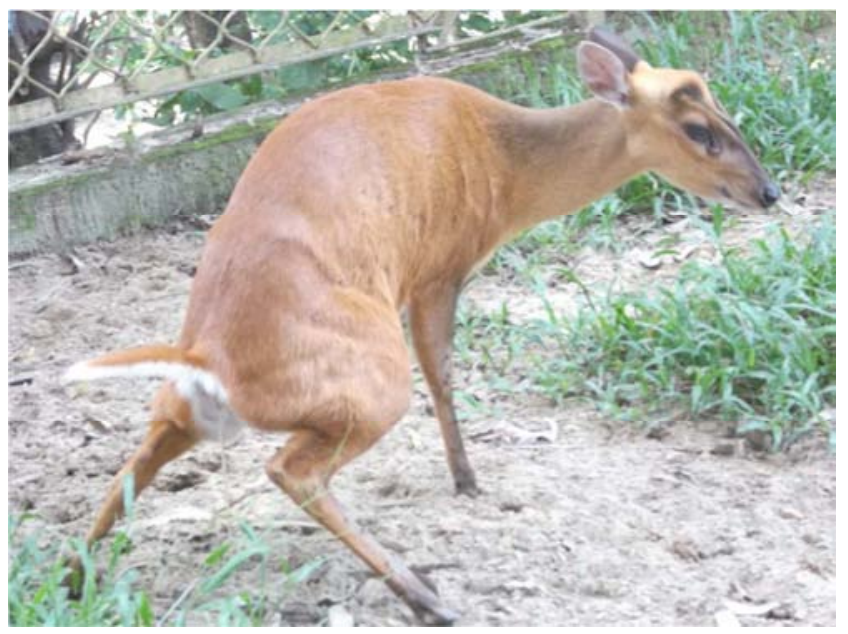

Figure 2. Female Barking Deer.

Table 4. Phenotypic Parameters of Barking Deer

\begin{tabular}{lll}
\hline Points & $\begin{array}{l}\text { Male Barking Deer } \\
\text { (Inch) }\end{array}$ & $\begin{array}{l}\text { Female Barking } \\
\text { Deer (Inch) }\end{array}$ \\
\hline Ear Length & $3.5 \pm 0.5$ & 3.5 \\
Fore Leg Length & 20 & 19 \\
Hind Leg Length & 22 & 21 \\
Tail length & 5.3 & 5.5 \\
Distance from ear to ear & 3.7 & 3.6 \\
Length of Antler & 3 & - \\
Time of growth of Antler & After 1 year & - \\
Drop outof Antler & Every 6 months after & - \\
Shedding of Antlers & During June-July & - \\
\hline
\end{tabular}

In this study, the ear's length of males \& females were $3.5 \pm 0.5 \mathrm{inch}$ and $3.5 \mathrm{inch}$. The length of foreleg for male and female were 20 and 19 inch and the length of hind leg for male and female were 22 and 21 inch. The length of antlers was 3 inch. This results is more or less similar to the findings of [13]. 
Table 5. Body weight measurement of barking Deer.

\begin{tabular}{llllll}
\hline \multicolumn{2}{l}{ Birth weight $\mathbf{( k g )}$} & \multicolumn{2}{l}{ Weight at Weaning (kg) } & \multicolumn{3}{l}{ Adult Weight(kg) } \\
\hline Male & Female & Male & Female & Male & Female \\
$1-1.5$ & $0.5-0.7$ & $10-12$ & $8-10$ & $25-30$ & $20-25$ \\
\hline
\end{tabular}

In this study the adult males and females weight were 25 $30 \mathrm{~kg}$ and $20-25 \mathrm{~kg}$ respectively, which is more or less similar to the findings of [15] (20-22 kg).

Average males and females weaning weights were $19.98 \pm 1.28$ and $18 \pm 1.05 \mathrm{~kg}$ and the highest and lowest weaning weights were $27.10,15.30 \mathrm{~kg}$ and $24.30,14.30 \mathrm{~kg}$, respectively in Dhaka Zoo [2] which is more or less similar to the findings of presented result. The weight were varied in several times may be due to the change in management and also change in weather condition of Chittagong zoo areas.

Table 6. Reproductive performance of Deer at Chittagong Zoo.

\begin{tabular}{llll}
\hline Criteria & Spotted Deer & Barking Deer & Sambar Deer \\
\hline Fawning season & All the months of the year except May & All the months of the year & All the months of the year $\quad$ All the months of the year \\
Age at puberty & 1.5 years & 1.5 years & $1.6-2.0$ years. \\
Length of estrous cycle & $14-22$ days & $12-20$ days & $16-24$ days \\
Gestation period & $7-8$ month & $6-7$ month & $6-8$ month \\
Numberof litters & 1 & 1 & 1 \\
Age at first fawning & $12-18$ months & $14-18$ months & $18-24$ months \\
Weaning age & $4-6$ months & $4-6$ months & $6-8$ months \\
\hline
\end{tabular}

In this study the average age at first fawning was ranging from 14-18 months; which is supported by [2] (14-18 months); (14-17 months) and [16] (1.5-2.0 years). In case of Vos finding it differs from our finding that it may be due to management as well as feeding practice differences. The length of estrous cycle was ranging from 12-20 days, which is more or less similar to the findings of [8] (17-24 days); [19] (12-23 days) and Azad et al., 2005 (14-21 days). The gestation period was ranging from 6-7 months, which is similar to the findings of [7] (6-7month); Chapple et al., 2003 (231-237 days). In this study the weaning age was ranging from 4-6 months, which is supported by the findings of [11] (16 weeks); [7][10] (12-20 weeks). Usual litter size in spotted deer is one rarely [1]. [2] Reported that the age of wearing was ranging from 4 to 6 months. Which is more or less similar to the findings of [2] (14-21 weeks); [11] (16 weeks) and [10] (12 to 20 weeks).

\section{Conclusion \& Recommendations}

The study was carried out to know the overall management of barking deer in captivity at Chittagong Zoo, giving more emphasis on phenotypic characters and reproductive parameters and feeding. This study was also revealed that the body coat color was reddish, "V" Shaped black colored forehead and black colored muzzle. The ear's length of males \& females were 3-4 inch and 3.5 inch. The length of foreleg for male and female were 20 and 19 inch and the length of hind leg for male and female were 22 and 21 inch. The length of antlers was 3 inch. Distance from ear to ear of male and female were 3.7 and 3.6 inch. The average birth weight of males and females barking deer were ranging from $1-1.5 \mathrm{~kg}$ and $0.5-0.7 \mathrm{~kg}$, males and females weaning weight were ranging from $10-12 \mathrm{~kg}$ and 08 $10 \mathrm{~kg}$ respectively and adult males and female's weight were ranging from $25-30 \mathrm{~kg}$ and $20-25 \mathrm{~kg}$ respectively. It was also observed that the weaning age, length $\mathrm{f}$ estrous cycle, age at first fawning and gestation length were ranging from 4-6 months; 12-20 days: 14-18 month and 6-7 month respectively.

The study revealed that the management of Barking Deer at Chittagong Zoo was partially standard in response to the actual standard means.

\section{References}

[1] Acharjo, L. N. and Mishra, C. G. 1981. Notes on weight and size at birth of eight species of Indian wild ungulates in captivity. J. Bombay. Nat Hist. Soc.77:504-507.

[2] Azad, M. A. K., Hossain, M. M. and Bhuiyan, A. K. F. H., 2005. Feeding and Managementof Spotted Deer at Dhaka Zoo. Int. J. of Zoo. Research (1): 48-52.

[3] Barrette, C. 1976. Musculature of facial scent glands in the muntjac. J. Anat., 122: 61-66.

[4] Barrette, C. 1977a. The social behavior of captive muntjacs, Muntiacus reevesi (Ogilby 1839). Z. Tierpsychol, 43: 188213.

[5] Barrette, C. 1977c. Some aspects of the behaviour of muntjacs in WilpattuNational Park, SriLanka Mammalia, 41:1-34.

[6] Chapman, D. I. and Dansie, O. 1970. Reproduction and feotal development in female muntjac deer (Muntiacus reevesi Ogilby). Mammalia, 34: 303-319.

[7] Chapman, N. G. 1993. Reproductive performance of captive Reeves' Muntjac. In: Deerof China: biology and management. N. Ohtaishi and H. I Sheng(eds.), Elsevier: 199-203.

[8] Chapman, N. G. 1997. Upper canine teeth of Muntiacus (Cervidae) with particular reference to M. reevesi. Z Saügetierk., Supp. II: 32-36.

[9] Dubost, G. 1971. Observations éthologiques sur le Muntjac (Muntiacus muntjac Zimmermann 1780 et M. reevesi Ogilby 1839) en captivité et semi-liberté. Z. Tierpsychol. 28: 387427.

[10] Flesch, J. S., Mulley, R. C. and Mulley, P. N., 1999. The growth rate and metabolisable energy intake of farmed fallow deer between 12 and 25 weeks of age. Australia Deer Farming, 10: 14-17. 
[11] Mulley, R. C. and Flesch, J. S., 2001. Nutritional requirements for pregnant and lactation red and fallow deer. A Report for the Rural Industries Research and Development Corporation. RIRDC Publication No. 110095. Canberra, Australia.

[12] Mulley, R. C., 1984. Reproduction in fallow deer. In: Deer refresher course forveterinarians. Proceedings No. 72, the University of Sydney, Sydney, pp: 463-464.

[13] Prater, S. H. 1997. The book of Indian Animals. Bombay Natural History Society, Bombay. Tenth impression, pp-294.

[14] Pei, K., Taber, R. D., O'hara, B. W. and Wang, Y. 1995. Breeding cycle of the for mosan Reeves' muntjac (Muntiacus reevesi micrurus) Northern Taiwan, Republic of China. Mammalia, 59: 223-228.

[15] Phillips, W. W. A. 1984. Manual of the mammals of Sri Lanka. Wildlife and nature protection society of Sri Lanka. $2^{\text {nd }}$ edition.
[16] Vos, A. D., 1982 Deer farming guidelines on practical aspects, food and AgricultureOrganization of the United Nations. Rome, Italy.

[17] Wemmer, C. (Ed.) 1998. Deer. Status survey and conservation action plan. IUCN/SSCDeer specialist group. IUCN, Gland, Switzerland and Cambridge, UK.

[18] Sarquist, 1999. Sundarban biodiversity conservation project: An overview. Intl. NotesNo. 79, pp: 4.

[19] Mylrea, G. E., Mulley, R. C., English, A. W. and Evans, G. 2004. Reproductive cycles of farmed female barkingDeer. CISR publishing- Reproduction, Fertility and Development, 11: 167-174.5. 